\title{
弾性体リンクによるリード・ラグ機構を有する 蝶型はばたきロボットの開発*
}

藤川太郎*1, 佐 藤 芳憲*2, 眞 方 勇 介*2 山下達 彦*2, 菊 池 耕 生*3

\section{Development of a Butterfly-Style Flapping Robot with Lead-Lag Mechanism Using Flexible Links}

\author{
Taro FUJIKAWA*4, Yoshinori SATO, Yusuke MAKATA, \\ Tatsuhiko YAMASHITA and Koki KIKUCHI \\ ${ }^{* 4}$ Department of Engineering, Chiba Institute of Technology, \\ 2-17-1 Tsudanuma, Narashino-shi, Chiba, 275-0016 Japan
}

\begin{abstract}
In this paper, we propose a small and simple slider-crank mechanism using flexible links that realizes both a wide flapping angle and lead-lag motion toward the development of a small flapping robot modeled on insects. Butterfly-style flight is attractive because of its low flapping frequency and fewer DOFs, unlike flies and dragonflies. However, since a butterfly flaps the wings over $150 \mathrm{deg}$ and claps both left and right wings, a conventional slider-crank mechanism cannot generate sufficient torque for flapping at the top dead point that the driver and follower are parallel. Furthermore, an additional actuator for lead-lag motion makes the mechanism heavy and complex. To overcome these problems, we developed a new slider-crank mechanism that can flap the wings widely by bending of the flexible links and that realizes the lead-lag motion by twisting them. The flight performance of the butterfly robot with this mechanism was comparable to that of a butterfly, unless a butterfly kicks ground at takeoff.
\end{abstract}

Key Words : Lead-Lag, Flapping, Slider-crank Mechanism, Flexible Link, Butterfly Robot

\section{1.}

近年, 極限環境における観測システムとして, Micro Air Vehicles（MAVs）等の小型飛行ロボットの開発が 進められている ${ }^{(1)(2)}$.中でも，狭险空間における移動性 や数 $\mathrm{G}$ を超える加速性を有する昆虫のはばたきは非常 に魅力的であり，その飛翔メカニズムの解明を目的と した研究が行われている(3)-(9). これらを基に，数十 $\mathrm{mg} \cdot$ 数十 $\mathrm{mm}$ オーダのハエや八チをモデルとした実機 開発が行われているが(10)(16)，その多くは未だ飛翔に至 っていないのが現状である，その理由として，ペイロ 一ドの問題から昆虫サイズのボディにバッテリーやア クチュエータを搭載することが非常に難しいこと，こ のサイズでは粘性項が支配的になりつつあり，リンク 数の増加が摩擦等によるエネルギー伝達効率の低下を 招くことなどが挙げられる．このような問題点を踏ま

* 原稿受付 2010 年 2 月 25 日

*1 正員, 千葉工業大学工学研究科(焉 275 0016 習志野市津田 沼 2-17-1).

*2 千葉工業大学工学部。

*3 正員, 千葉工業大学工学部.

E-mail : fujikawa.gf $0 @$ gs.it-chiba.ac.jp
え, 著者らは, 八エなどと比較して $10 \mathrm{~Hz}$ 程度と低い はばたき周波数で質量約 $500 \mathrm{mg}$, 翼幅 $100 \mathrm{~mm}$ 程度の 蝶をモデルとしたはばたきロボットの開発を行ってき た(17).アクチュエータとしてゴムを採用し，捻ること で生じる回転エネルギーを利用することでバッテリー や減速機等を必要とせず，はばたき機構に弾性体リン クを用いることによって少ないリンク数で蝶と同等で ある $150^{\circ}$ 程度の大きなフラッピング角を実現した. ここで, 蝶のはばたきメカニズムにおける他の飛翔昆 虫と大きく異なる特徴として, 翅の打ち下ろし時に体 を起こしながら上昇し，翅の打ち上げ時に体を戻しな がら前進するという階段状の飛翔を行っていることが 挙げられる. つまり, 蝶は体全体のピッチ角を変化さ せることでフェザリング（空力中心周りの翅の捻り） と同等の運動を行い, 飛翔時の姿勢制御を行っている ものと考えられる. このとき，フラッピング（翅を体 軸周りに上下させる）と共にリード・ラグ（翅を体軸 と平行に前後させる）を行っていることが確認されて いるが(18)，飛翔時におけるこれらの運動と姿勢制御义 カニズムに関しては未だ明らかにされていない部分が 多い，さらに，実機製作を考えた場合，既存のはばた 
き機構でフラッピング運動の他にフェザリングやリー ド・ラグ運動を行うためには, リンク数の増加や各運 動のためのアクチュエータの追加など, 機構の複雑化 や大型化を伴う.

以上の視点から，本論文では，はばたきロボットに よる飛翔実験によってリード・ラグ運動とその飛翔制 御メカニズムを明らかにするため, リンクの撓みと捻 れのみを利用することでフラッピングとリード・ラグ の 3 次元的な運動を可能とする小型且つ単純な機構を 提案する. そして，本機構を実装した蝶型はばたき口 ボットを開発して飛翔運動解析を行うことにより，そ の有効性を実証する.

以下, 本論文の構成は次の通りである. 2 章では, はばたきロボットの設計パラメータを設定するため, 蝶の飛翔運動解析を行う. 次に 3 章では, 2 章での解. 析結果を基にここれまでに著者らが開発した弾性体リ ンクによるはばたき機構を応用したリード・ラグ機構 を設計し，本機構を実装したはばたきロボットを開発 する. 4 章では, その飛翔運動解析を行う. 最後に, 5 章で結言と今後の課題を述べる.

\section{2. 蝶の飛翔远功解析}

ナミアゲハ (Papilioxuthus) をモデルとし, 飛び立 ち時の様子を 3 次元高速度カメラシステム $(640 \times 480$ pixels, 200fps）を用いて, $x, y, z$ 方向から撮影した. 図 1 は $\mathrm{x}$ 方向から撮影した蝶の典型的な 1 はばたきの $1 / 8$ 周期毎の連続写真である. 得られた画像より, 図 2 に定義するパラメータに従って, フラッピング角, ボ ディピッチ角, 及び，リード・ラグ角を測定し，飛翔 時間 $\mathrm{t}[\mathrm{msec}]$ をはばたき 1 周期の時間 $\mathrm{T}[\mathrm{msec}]$ で正規 化した. 図 3，4 は，それぞれフラッピング運動の 2 倍周期のリード・ラグ璭動, 及び，同周期のリード・ ラグ運動を行っていた飛翔に関する解析結果の典型例 である.また，そのときの胸部軌跡と加速度の変化の 様子をそれぞれ図 5，6 に示寸. 図 3，4より，2 倍周 期の飛翔においては，翅打ち下ろし，及び，打ち上げ 時のフラッピング速度が最大となるフラッピング角 $10^{\circ}$ （フラッピング角の中間值）近傍で, 同周期の飛 翔においては翅打ち下ろし終了間際に前進翼角が最大 となるリード・ラグ運動を行っていることが確認でき る. このとき, 翅の揚力中心は前方へ移動することで 重心位置から最も離れ, 且つ, 翅面積が最大となって いることを示す. ボディピッチ角の推移に着目すると, 両飛翔においてその值は翅打ち下ろし時に前進翼角が 最大となった後に増加し始め, 翅打ち上げ時に最大と なっていることがわかる. リード・ラグ運動の影響を
考慮すると，揚力中心が重心位置と最も近接した状態 から翅打ち下ろしと共に前方へ移動することにより， 揚力によるボディの回転トルクも徐々に大きくなり, ボディピッチ角速度も徐々に増すことに起因すると推 測される.このことから, 蝶はリード・ラグ運動を行 うことで揚力中心と重心位置との距離を変化させ, ボ ディピッチ角を制御することで, 翅打ち下ろし時に体 を起こしながら $\mathrm{z}$ 方向一加速し（図 5,6のa）, 翅打 ち上げ時に $\mathrm{x}$ 方向一加速する（図 5，6のb) 階段状の 飛翔を行っていると考えられる.
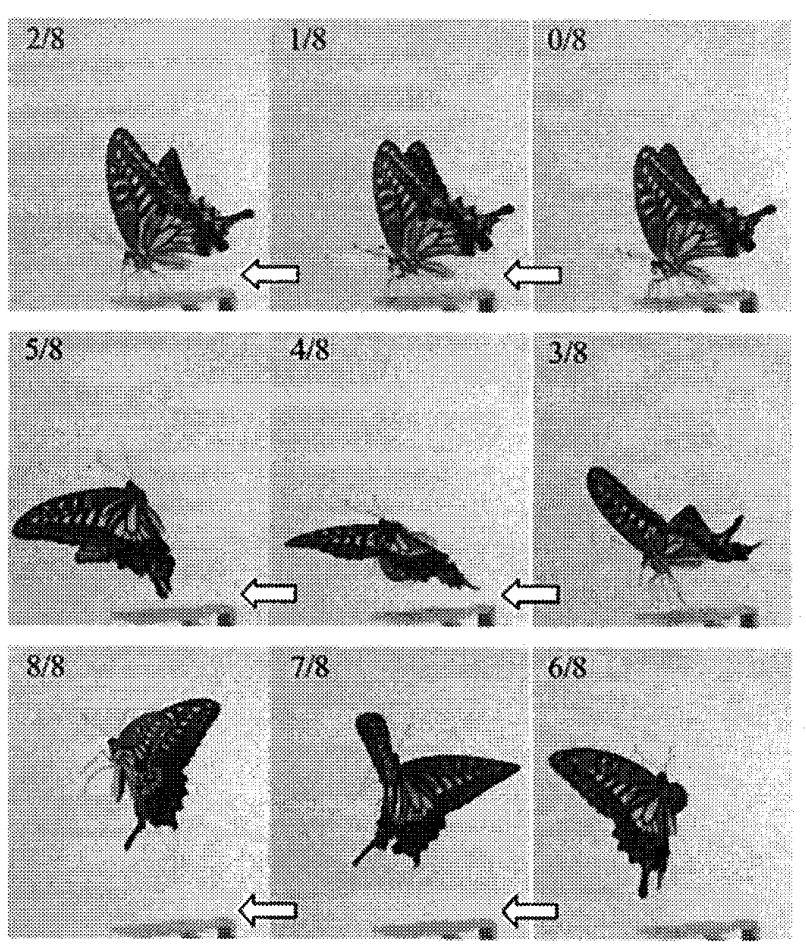

Fig. 1 Stroboscopic photographs of a butterfly taken during takeoff

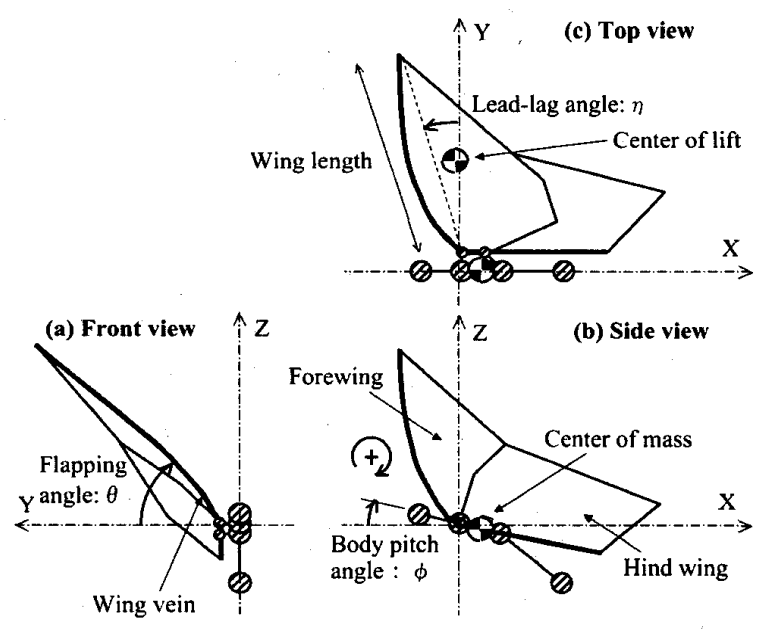

Fig. 2 Definition of parameters for butterfly-style flight 


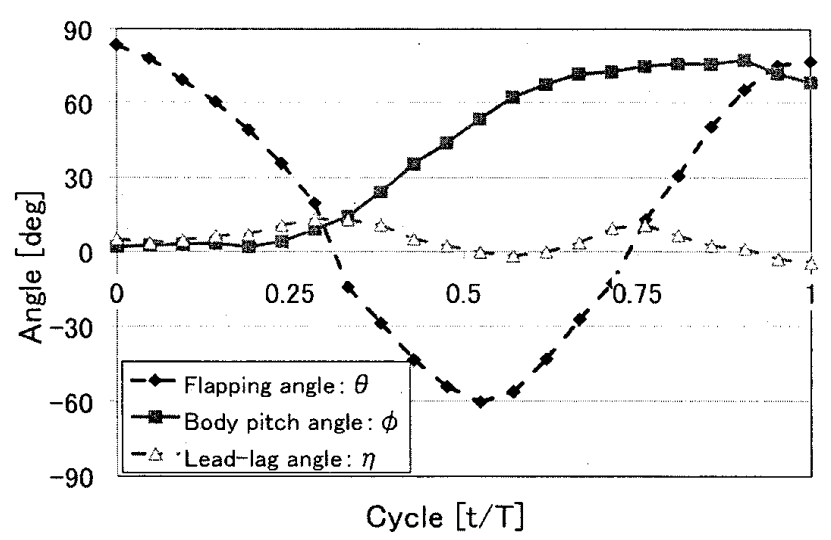

Fig. 3 Relationship among flapping, lead-lag, and body pitch angles of a butterfly (twofold cycle case)

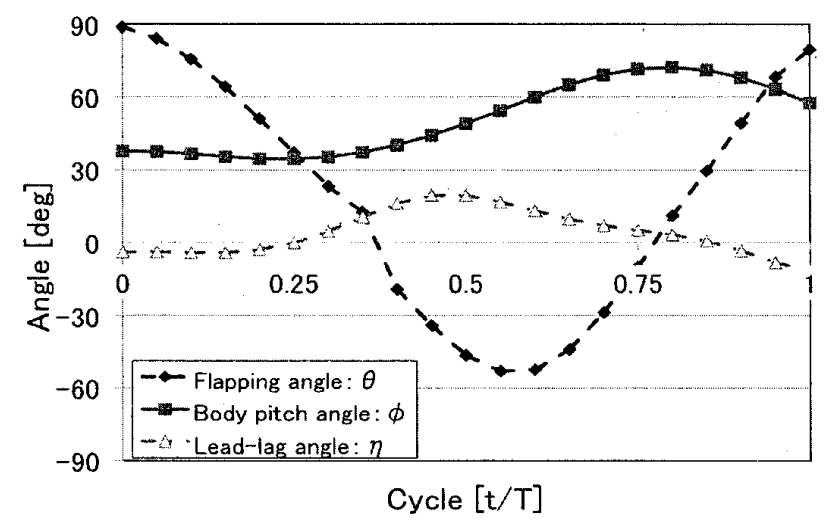

Fig. 4 Relationship among flapping, lead-lag, and body pitch angles of a butterfly (same cycle case)

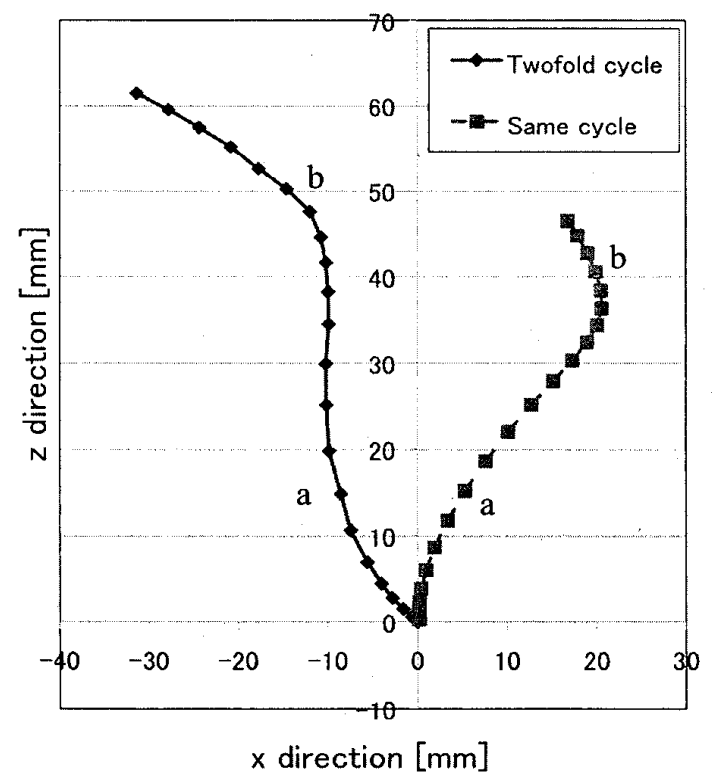

Fig. 5 Trajectories of center of thorax for butterflies during takeoff

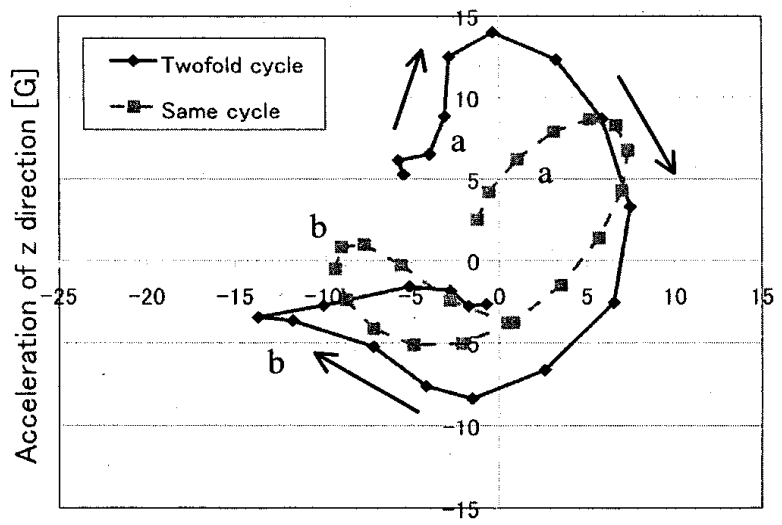

Acceleration of $x$ direction [G]

Fig. 6 Acceleration of center of thorax for butterflies during takeoff

\section{3. フラッピング及びリード・ラグ機構を有する 蝶型はばたきロボットの開発}

蝶はフラッピング運動の 2 倍周期, または同周期で リード・ラグ運動を行っていることが 2 章の解析結果 より確認され，これに伴い，揚力中心の位置を変化さ せていることが示唆された. 本論文では，蝶と同様に これらの運動を行う新たな機構設計の第一段階として, 翅打ち上げ時により前方一飛翔している解析結果を得 た 2 倍周期のリード・ラグ機構を提案し，この機構を 実装した蝶型はばたきロボットを開発する.

既存のはばたき機構を用いてフラッピング運動と同 時にリード・ラグ運動を再現しようとする場合, リン ク数の増加やアクチュエータの追加等により, その機 構は複雑化, 且つ, 大型化を伴っていた. 1 章で述べ たように，昆虫のスケールでは粘性項が支配的になり つつあるため, リンク数の少ない単純な機構が求めら れる. そこで, 本研究では, 著者らがこれまでに開発 した弾性体リンクを用いた往復摇動機構を応用し，リ ンクの撓みと捻れを利用することにより，フラッピン グ運動とリード・ラグ運動を行う往復摇動機構を提案 する. 本機構を実装した蝶型はばたきロボットの CAD モデルの俯瞰図, 及び, フラッピング上死点と下死点 の状態図をそれぞれ図 7，8に示す．尚，機構を明確に するため，両図に沶いて左翅は省略してある．製作す るロボットの翅は, 蝶と同様にフラッピング, 及び, リード・ラグ運動を行う前翅左右 2 枚とフラッピング 運動のみを行う後翅左右 2 枚の計 4 枚とし, 後翅はX 軸回転が可能な翅基部に取り付ける. 前翅は翅基部に 取り付けられた Z 軸回転が可能なユニバーサル・ジョ イントに接合され，このジョイントは弾性体リンクに よって下部ボディと連結される，この際，リンクを撓 
みによる復元力が生じない自然状態（文献 17 参照）に おいて取り付け角 $\alpha$ で取り付けることにより，リンク には捻れが生じず，この取り付け角 $\alpha$ が前翅の最大前 進翼角度となる. 動力には出力質量比に優れたゴムの 弾性エネルギーを利用し，捻りによる回転運動をスラ イダとクランクを通すことにより，上部ボディの上下 往復運動に換える. この運動によるリンクの撓みでユ ニバーサル・ジョイントの軸線 X 周りに前翅と後翅が フラッピング運動を行い，このとき生じるリンクの捻 れによって同ジョイントの軸線 $\mathrm{Z}$ 周りに前翅がリー ド・ラグ運動を行うことが可能となる.ここで，提案 する機構によるリード・ラグ運動のメカニズムの詳細 について, 図 9 から図 13 を用いて説明する. 図 9 は, フラッピング上死点（図 8(a)）からの翅打ち下ろし開 始時, 図 10 は, 弾性体リンクに撓みによる復元力が生 ごていないはばたき中立点(ここでは $\theta=0^{\circ}$ に設定)， 図 11 は翅打ち下ろし終了時でのフラッピング下死点 （図 8(b)）における翅基部の拡大図である．また，図 12，13 は，フラッピング下死点からの翅打ち上げ開始 時，及び，翅打ち上げ終了時のフラッピング上死点に おける翅基部の拡大図である。弾性体リンクは，はば たき中立点から上死点に移行することにより撓みと共 にラグ方向に捻れが生じる. フラッピング運動はこの 状態から開始されるため, 翅打ち下ろし行程において ラグ方向に回転していた前翅を戻そうとするモーメン トMによって軸線Z周りのリード方向一の回転トルク $\tau_{\text {tead }}$ が生じる（図 9）。そして，前翅はリード運動を しながら図 10 に示すはばたき中立点へと達し，捻れが 生じない状態になる。このとき，前進翼角度は最大と なるため $(n=\alpha)$ 揚力中心と重心位置との距離は最大 となり，且つ，翅面積も最大となる．はばたき中立点 を超えた弾性体リンクは再びラグ方向への捻れを生じ, その捻れを元に戻そうとするモーメントによる回転卜

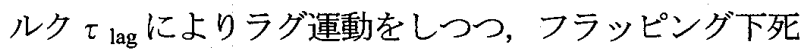
点に至る（図 11）。次に翅打ち上げ行程において，打 ち下ろし行程と同樣に捻れを戻そうとするモーメント によって生じた回転トルク $\tau_{\text {lead }}$ によりリード運動を 行い（図 12），翅打ち下ろし時同様にはばたき中立点 において前進翼角が最大となるため，揚力中心と重心 位置間の距離，及び，翅面積は最大となる（図 10）. そして，その後生じたラグ方向への捻れを元に戻そう とするモーメントにより発生した回転トルク $\tau_{\mathrm{lag}}$ によ り，前翅はラグ運動を行ってフラッピング上死点に至 る（図 13）。この動作を繰り返すことにより，スライ ダの上下往復運動の 1 自由度のみでフラッピング運動 と共に 2 倍周期でのリード・ラグ運動が可能となる.
尚, この機構における弾性体リンクの撓みと捻れの タイミングを調整することにより，フラッピング運動 と同周期でのリード・,ラグ運動も可能であると考えら れる.

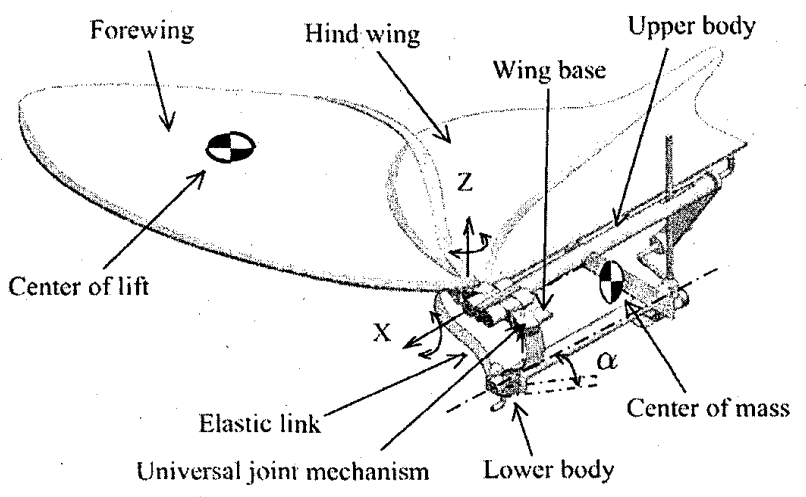

Fig. 7 Overview of CAD model

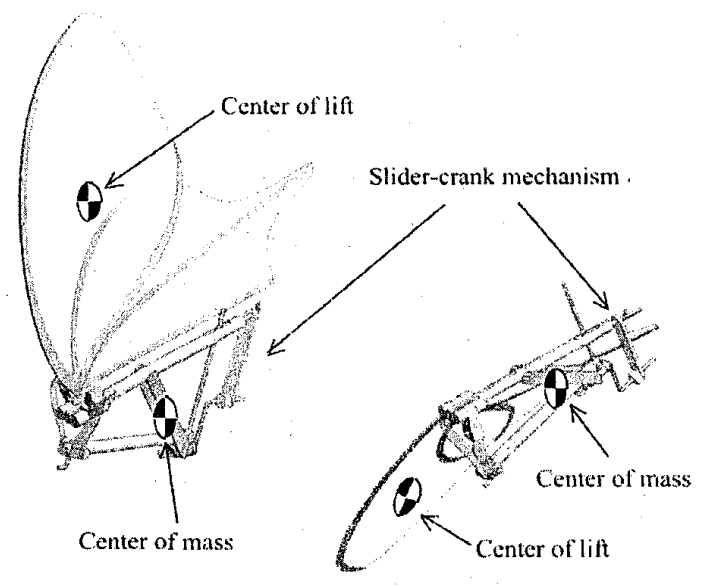

(a) Top dead point

(b) Bottom dead point

Fig. 8 Flapping motion of CAD model
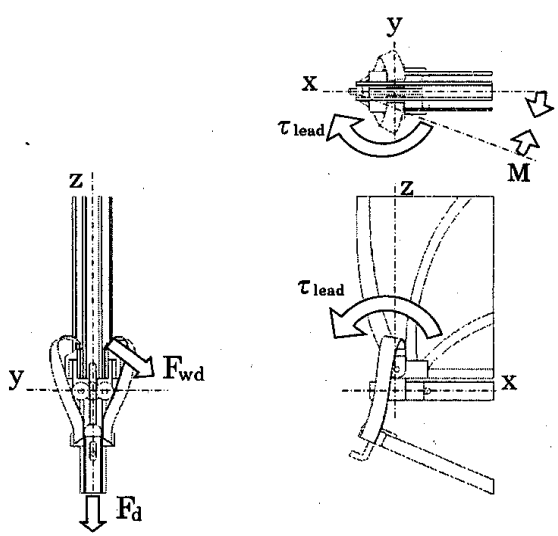

Fig. 9 Lead-lag motion at the top dead point during down stroke 

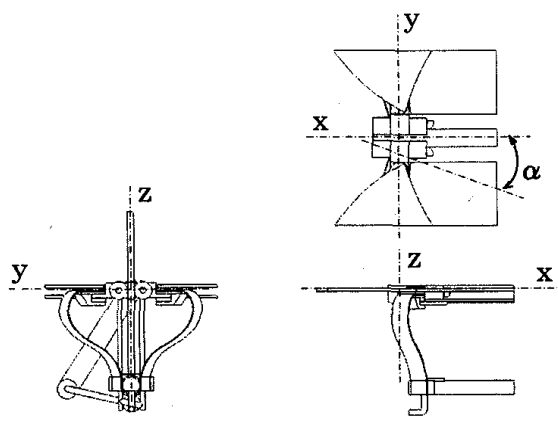

Fig. 10 Lead-lag motion at neutral position
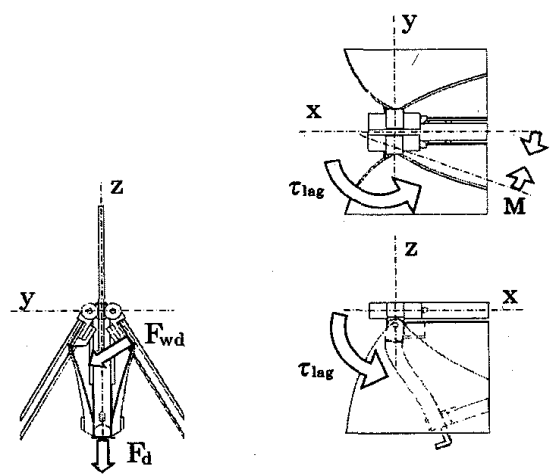

Fig. 11 Lead-lag motion at the bottom dead point during down stroke
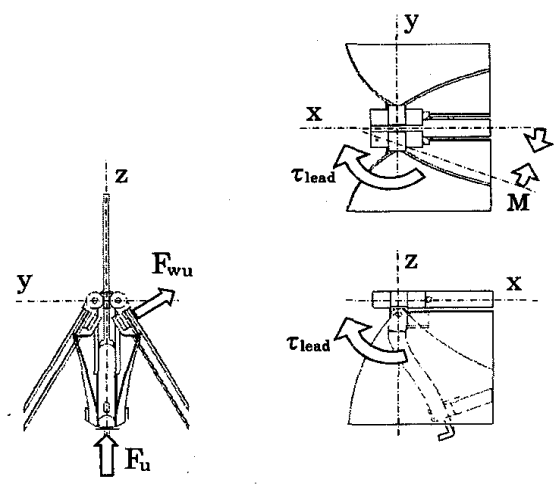

Fig. 12 Lead-lag motion at the bottom dead point during upstroke

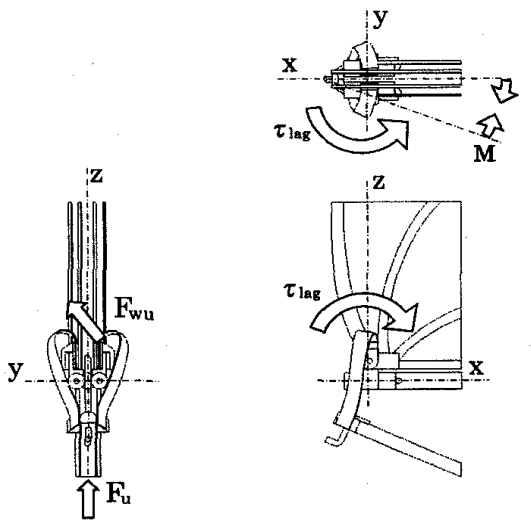

Fig. 13 Lead-lag motion at the top dead point during upstroke

\section{4. 蜼型はばたきロボットの飛翔远阮解析}

本章では,リード・ラグ機構の有無による蝶型はば たきロボットの飛翔運動解析を行い，蝶の解析結果と 併せて比較することで提案する機構の有効性を示す.

4・1 パラメータ設定 使用するロボットは 3 章で設計したモデルであり，リード・ラグ機構を有す る Type A と前進翼角度を固定した Type B の2 種類を 用いる：前翅長は $53 \mathrm{~mm}$, 後翅の翼弦長は $40 \mathrm{~mm}$ であ り，はばたき時の後縁部の捲れを防ぐために後翅には 梁を入れてある．翅とボディを構成する主な材質には 比剛性に優れた竹ひごを使用し，翅膜にはポリエチレ ン性の薄膜を用いている. 全体の質量はアクチュエー タとするゴムを含めて約 $500 \mathrm{mg}$ となり, モデルとした ナミアゲハと同サイズ同質量である. Type A のフラッ ピング角とリード・ラグ角は 2 章での蝶の解析結果を 基に，翅打ち下ろし角 $80^{\circ}$ ，打ち上げ角 $-60^{\circ}$ ，最大 リード角 $15^{\circ}$ ，最大ラグ角を- $5^{\circ}$ と設定した。比較に 用いる Type B のフラッピング角はType A と同等であ り，前進翼角は Type A の中間值である $10^{\circ}$ とした. 尚, 本実験において比較する蝶の解析結果は 2 倍周期 でリード・ラグ運動を行うケースであるため, 図 3 よ り初期ボディピッチ角を $0^{\circ}$ と設定し, 実験を行った.

4.2 はばたきロボットの我看迅功解析 2 章 での蝶の連動解析と同様に 3 次元高速度カメラシステ ムを用いて Type A と Type B の飛び立ちからの飛翔の 様子を撮影し，画像処理による解析を行った. フラッ ピング角, ボディピッチ角, 及び, リード・ラグ角の 関係について, Type A と Type B の解析結果をそれぞ れ図 14,15 に示す. 図 16,17 は Type A と Type B $の$ 飛び立ちからの 1 はばたきにおける飛翔軌跡, 及び, 加速度の推移を比較したものであり，図 18 は Type A の飛翔の様子を撮影した 1/8 周期毎の連続写真である. また, Type A と Type B の 10 回の試行結果における 翅打ち下ろし時のピッチ角と飛翔高さ，及び，前進移 動距離の平均值と偏差を表 1 に示す，図 14 より, 本機 構を実装した Type A は, 蝶と同様にフラッピング運 動の 2 倍周期でリード・ラグ運動を実現していること が確認できる. ボディピッチ角の推移に着目すると, その極大值は, Type B では翅打ち下ろし直後の平均約 $38^{\circ}$ であるのに対し, Type A は蝶と同様に翅打ち上 げ時に約 $65^{\circ}$ を示していることがわかる.リード・ラ グ運動により, Type A は翅打ち下ろし終了時の揚力中 心が Type B よりも重心位置に近いため, 翅打ち上げ による負の方向の回転トルクもより小さな值から極大 を迎える.よって，翅打ち下ろしによる正方向の回転 
トルクは Type B に比べて徐々に減少するため, その 值は Type B よりも増加したものと思われる. 次に, 図 16，17，及び，表 1 より，Type B が翅打ち下ろし 終了時にほぼ最大飛翔高さまで上昇したのち下方へ飛 翔しているのに対し (図 16, 17 の $a_{B}, b_{B}$ ), Type A は翅打ち下ろしで上方一加速し（図 16,17 の $\mathrm{a}_{\mathrm{A}}$ ) , 自重を支えるだけの揚力を維持しつつ前方一加速して いることが確認できる（図 16,17 の $b_{A}$ ）。これは, 翅打ち下ろし終了時のピッチ角がより大きい Type A では翅打ち上げ時に翅が受ける反力の $\mathrm{z}$ 方向成分が Type B よりも小さいため, 下方への加速度が小さくな ったことによると考えられる. しかし，翅打ち下ろし 時の飛翔高さに着目すると, Type A, B 共に蝶の $1 / 4$ 程度であることが図 5 と図 16 の比較から確認できる. 蝶は脚で地面を蹴るようにして飛び立ちを開始してお り, 本解析では約 5G の初期加速度が観測された（図 6). しかし，本実験におけるはばたきロボットの飛び立ち は，開放機により初期加速度がほぼ $0 \mathrm{G}$ の状態から開 始される（図 17）。つまり，蝶は床反力により $\mathrm{z}$ 方向 への加速度を発生させて飛翔することで図 5 に示され る飛翔高さを得ているものと考えられ，今後は，はば たきロボットの飛翔運動解析においてもこの初期加速 度を考慮に入れた実験を行うことが必要である.

以上の結果から，提案するリード・ラグ機構をはば たきロボットに実装することにより，飛翔時における 翅の揚力中心を前後に移動させることでボディの回転 トルクが制御可能であることが示された.これにより， 初期ボディピッチ角 $0^{\circ}$ からの飛び立ちにおいて, 蝶 と同様に翅打ち下ろしで上昇し，打ち上げで落下せず に前方へ飛翔することが可能となった。 今後は，本機 構を実装したロボットにより，リード・ラグ運動と飛 翔時の姿勢制御メカニズムの関連性について明らかに していくことが課題となる.

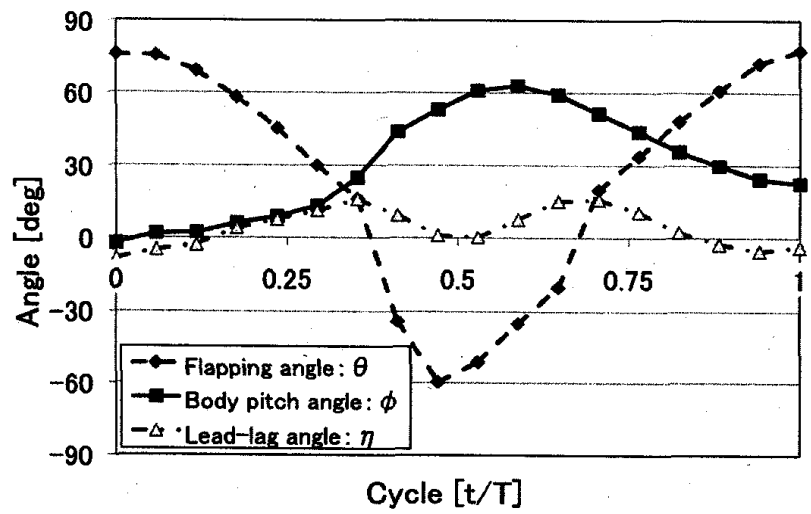

Fig. 14 Relationship among flapping, lead-lag, and body pitch angles of Type $A$

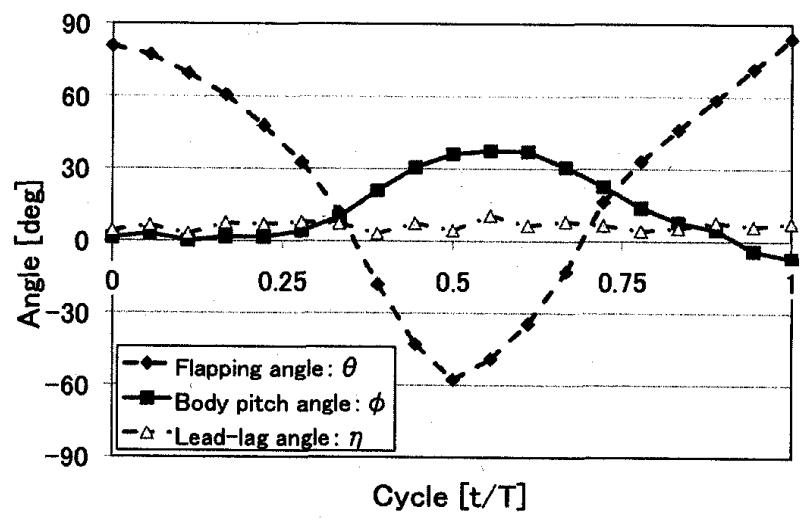

Fig. 15 Relationship among flapping, lead-lag, and body pitch angles of Type B

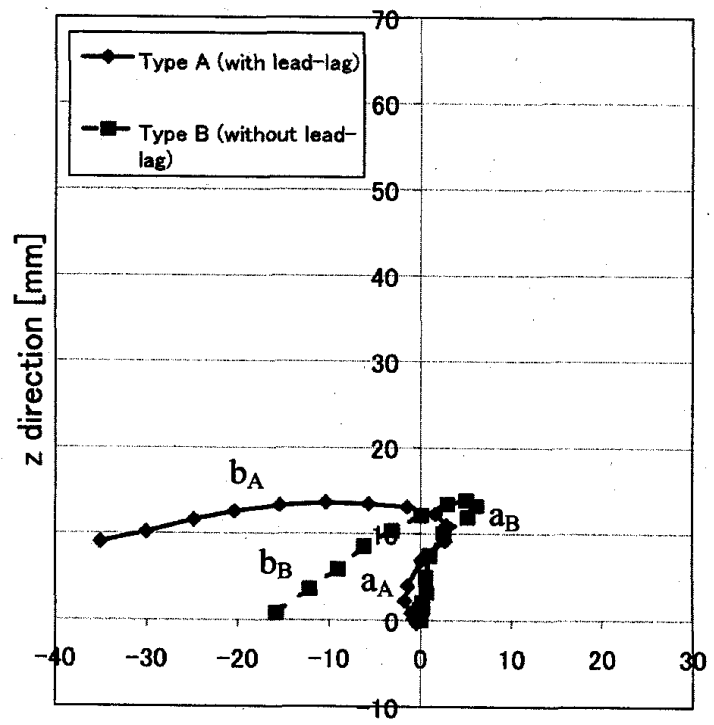

$x$ direction $[\mathrm{mm}]$

Fig. 16 Trajectory of center of thorax for Types A and B during takeoff

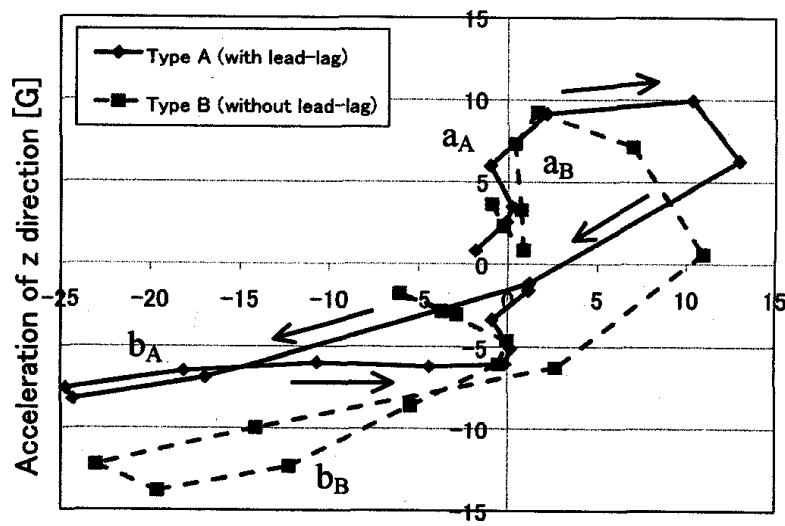

Acceleration of $x$ direction [G]

Fig. 17 Acceleration of center of thorax for Types $A$ and $B$ during takeoff 


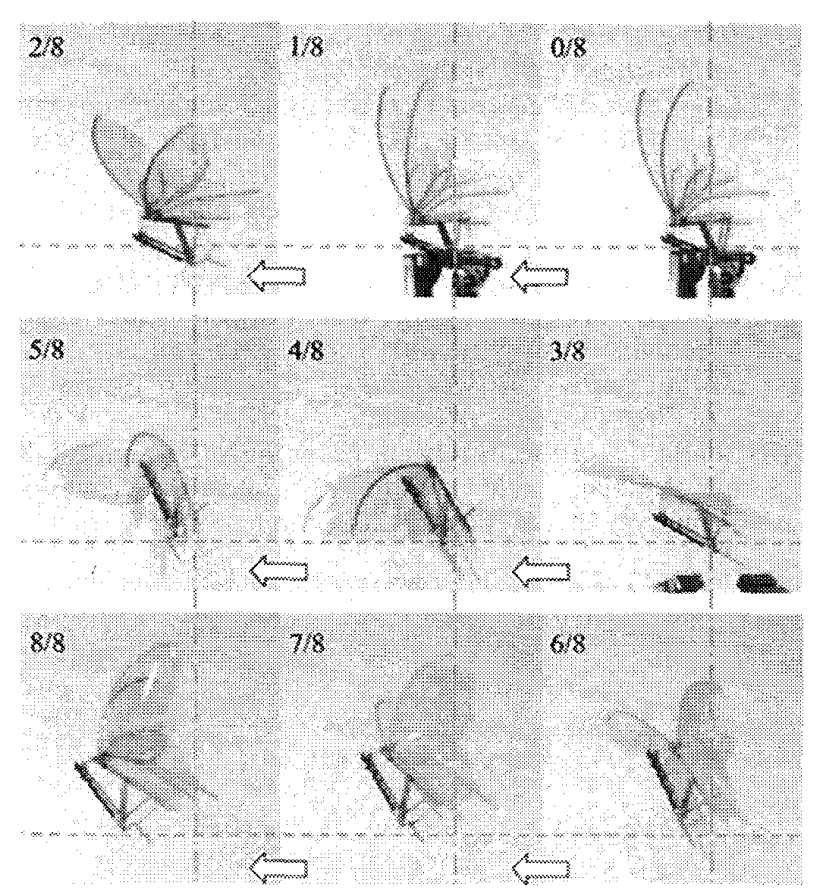

Fig. 18 Stroboscopic photographs of Type A taken during takeoff

Table 1 Results of takeoff for Types A and B

\begin{tabular}{c|c|c|c|c}
\hline \multirow{2}{*}{ Index } & \multicolumn{2}{|c|}{ Type A } & \multicolumn{2}{c}{ Type B } \\
\cline { 2 - 5 } & Ave. & Std.dev & Ave & Std.dev \\
\hline $\begin{array}{c}\text { Maximum of pitch } \\
\text { angle [deg] }\end{array}$ & 64.7 & 2.9 & 37.7 & 2.4 \\
\hline $\begin{array}{c}\text { Flight height for } \\
\text { down stroke [mm] }\end{array}$ & 8.4 & 0.8 & 10.2 & 0.9 \\
\hline $\begin{array}{c}\text { Maximum height } \\
\text { [mm] }\end{array}$ & 12.1 & 2.1 & 11.7 & 0.8 \\
\hline $\begin{array}{c}\text { Distance for flight } \\
{[\mathrm{mm}]}\end{array}$ & 26.5 & 3.7 & 17.2 & 4.5 \\
\hline
\end{tabular}

\section{5.}

本論文では, 蝶型はばたきロボットの開発を目指し, フラッピング運動と共にリード・ラグ運動を再現可能 な機構を提案した。 また，本機構を実装したロボット の飛翔実験を行うことにより，その有効性を示した. 得られた結果は以下の通りである.

（1）弾性体リンクの撓みと捻れを利用することにより， スライダ・クランク機構における上下往復運動の 1 自由度のみで $150^{\circ}$ 以上のストロークをもつフ ラッピング，及び, リード・ラグを伴った 3 次元 的な運動を行うことが可能になった。

(2) 前翅のリード・ラグ運動によりボディピッチ角を 制御し, 蝶とほぼ同様の $0^{\circ}$ から $65^{\circ}$ の周期運動 を実現した。
（3）蝶とほぼ同等の最大ボディピッチ角を実現するこ とにより，翅打ち上げ時においても自重を支える だけの揚力が維持され，且つ，より前方へ飛翔す ることが可能になった。

今後の課題は, フラッピング運動と同周期でリー ド・ラグ運動を行う新たな機構の開発, リード・ラグ 運動による姿勢制御メカニズムの解明，脚の蹴り動作 による初期加速度を考慮に入れた飛翔実験などが挙げ られる.

\section{辞}

本研究の一部は日本学術支援会（JSPS）の 2005 年 若手研究（A），17686022 の補助金によって行われた ものであり，ここに記して謝意を表する.

\section{文献}

(1) E. W. Green and P. Y. Oh, Autonomous Hovering of a Fixed-Wing Micro Air Vehicle, Proceedings of 2006 IEEE International Conference on Robotics and Automation, (2006), pp. 2164-2169.

(2) Hazawa, K., Nonami, K., et al., Autonomous Flight Control of Hobby-Class Small Unmanned Helicopter -Trajectory Following Control by Using Preview Control Considering Heading Direction-, Proceedings of 2004 IEEE/RSJ International Conference on Intelligent Robotics and Systems: IROS2004, (2004), CD-ROM.

(3) T. Weis-Fogh, Quick Estimates of Flight Fitness in Hovering Animals, Including Novel Mechanisms for Lift Production, J. Exp. Biol., Vol. 59, (1973), pp. 169-230.

(4) M. H. Dickinson, F. Lehmann, and S. P. Sane, Wing Rotation and the Aerodynamic Basis of Insect Flight, Science, Vol. 284, (1999), pp. 1954-1960.

(5) S. P. Sane and M. H. Dickinson, The Control of Flight Force by a Flapping Wing: Lift and Drag Production, J. Exp. Biol., Vol. 204, (2001), pp. 2607-2626.

(6) F. Lehmann, Aerial Locomotion in Flies and Robots: Kinematic Contorol and Aerodynamics of Oscillating Wings, Arthopod Structure and Development, Vol. 33, (2004), pp. 331-345.

(7) S. A. Combes and T. L. Daniel, Flexural Stiffness in Insect Wings I. Scaning and the influence of wing venation, J. Exp. Biol., Vol. 206, (2003), pp. 2979-2987.

(8) Sunada, S., Kawachi, K., et al,. Performance of a Butterfly in Take-off Flight, J. Exp. Biol., Vol. 183, (1993), pp. 249-277.

(9) Sudo, S. and Tsuyuki, K., The Wing Apparatus and Flapping Behavior of Hymenoptera, Transactions of the Japan Society of Mechanical Engineers, Series C, Vol. 44, No. 4, 2001, pp. 1103-1101.

(10) X. Deng, L. Schenato, W. Chung Wu, and S. S. Sastry, Flapping Flight for Biomimetic Robotic Insects: Part I - System Modeling, IEEE Trans. Rob., Vol. 22, No. 4, (2006), pp. 776-788.

(11) X. Deng, L. Schenato, W. Chung, and S. S. Sastry, Flapping Flight for Biomimetic Robotic Insects: Part II - Flight Control Design, IEEE Trans. Rob., Vol. 22, No. 4, 2006, pp. 789-803. 
(12) R. S. Fearing, K. H. Chiang, M. H. Dickinson, D. L. Pick, M. Sitti and J. Yan, Wing Transmission for a Micromechanical Flying Insect, proceedings of IEEE International Conference on Robotics and Automation, (2000), pp. 1509-1516.

(13) R. J. Wood, The First Takeoff of a Biologically Inspired At-Scale Robotic Insect, IEEE Trans. Rob., Vol. 24, No. 2, (2008), pp. 341-347.

(14) R. J. Wood, Design, fabrication, and analysis of a 3 DOF, $3 \mathrm{~cm}$ flapping-wing MAV, proceedings of IEEE International Conference on Intelligent Robots and Systems, (2007), pp. 1576-1581.

(15) M. Sitti et al., Development of PZT and PZN-PT Based Unimorph Actuators for Micromechanical Flapping Mechanisms, Proceedings of IEEE
International Conference on Robotics and Automation, (2001), pp. 3839-3846.

(16) M. Sitti, PZT Actuated Four-Bar Mechanism with Two Flexible Links for Micromechanical Flying Insect Thorax, proceedings of IEEE International Conference on Robotics and Automation, (2001), pp. 3893-3900.

(17) Fujikawa, T., Kikuchi, K., et al., Development of a Butterfly-style Flapping Robot with Slider-crank Mechanism using Flexible Links, Transactions of the Japan Society of Mechanical Engineers, Series C, Vol. 76, No. 761, 2010, pp. 151-157.

(18) Senda, K., et al., Study on Flapping-of-Wings Flight of Butterfly with Numerical and Experimental Analysis, AIAA, Vol. 1, (2006), pp. 452-467. 